\title{
"O GRITO DO IPIRANGA" E A PERSISTÊNCIA DO TÓPOS HISTÓRICO (UM POEMA INÉDITO DE MACHADO DE ASSIS)
}

\section{WILTON JOSÉ MARQUES}

Universidade Federal de São Carlos

São Carlos, São Paulo, Brasil

Resumo: $\mathrm{O}$ artigo apresenta a leitura de um poema inédito de Machado de Assis, "O grito do Ipiranga", publicado no jornal Correio Mercantil, em setembro de 1856. Além disso, discute duas crônicas que usam o mesmo tópos histórico do poema, retirado da História de Roma, de Tito Lívio.

Palavras-chave: Machado de Assis; "O grito do Ipiranga"; crônicas; Tito Lívio.

\section{"THE CRY OF IPIRANGA" AND THE PERSISTENCE OF THE HISTORIC TOPOS (AN UNPUBLISHED POEM BY MACHADO DE ASSIS)}

Abstract: This article offers a reading of a barely known poem by Machado de Assis, "The Cry of Ipiranga," published in the newspaper Correio Mercantil, in September 1856. Additionally, it addresses two chronicles that use the same historical topos of the poem, taken from History of Rome, by Titus Livius.

Keywords: Machado de Assis; "The Cry of Ipiranga"; Chronicles; Titus Livius. 
Entretanto, [...] copiei os versos, [...], e levei-os ao Correio Mercantil, onde um amigo me fez of favor de os publicar na parte editorial.

"Uma por outra", Machado de Assis.

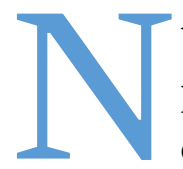

uma longínqua segunda-feira do mês de setembro de 1856, a primeira página do Correio Mercantil informava, em comunicado especial aos leitores, o então falecimento do "decano do Senado, o sr. marquês de Valença, o único que restava dos primeiros senadores escolhidos pelo sr. d. Pedro I em 22 de janeiro de 1825", e, logo abaixo, a coluna "Notícias Diversas", caixa de ressonância dos acontecimentos recentes, repercutia, com o mais "vivo ardor patriótico", os eventos que, no dia anterior, 7 de setembro, marcaram as comemorações da Independência do Brasil na capital do Império. Naquele ano, para o anônimo redator, a população festejou "entusiasticamente o aniversário da independência nacional” e, por isso mesmo, saudou "com fervor o monarca em todos os lugares onde ele aparecia [...]” (CORREIO MERCANTIL, 1856, p. 1).

Na segunda página, o jornal liberal trazia, na seção "Variedade", um poema, de título e temática apropriados à ocasião, "O grito do Ipiranga". Datado de 7 de setembro de 1856, era assinado - por extenso, em caixa-alta e com direito a ponto de exclamação no final - por um ainda desconhecido poeta de apenas dezessete anos, seu nome: "JOAQUIM MARIA MACHADO DE ASSIS!" (ASSIS, 1856, p. 2).

Embora o poema seja igualmente desconhecido por leitores e pela crítica literária, sobretudo a crítica machadiana, o que, inclusive, ajudou a corroborar o seu ineditismo, ${ }^{1}$ já que nunca fora antes coligido, ${ }^{2}$ e, ao mesmo tempo, em razão de a própria crítica até então acreditar que tinha sido outro poema - "Esperança", dedicado ao amigo Gonçalves Braga e publicado em 25 de outubro de 1858 (ASSIS, 1858, p. 2) - a primeira colaboração de Machado

\footnotetext{
${ }^{1}$ Para a história da descoberta de "O grito do Ipiranga", confira COZER, Folha de S.Paulo, 2015, p. E-1.

${ }^{2}$ O poema não consta, por exemplo, da clássica edição da Bibliografia de Machado de Assis, de Galante de Sousa (1955), nem do também clássico Dispersos de Machado de Assis, organizado por Jean-Michel Massa (1965).
} 
de Assis no Correio Mercantil, ${ }^{3}$ agora, no entanto, sabe-se que a primazia coube a "O grito do Ipiranga".

De saída, é possível conjecturar que a redescoberta deste texto de juventude, e, portanto, mais sujeito a influxos estéticos, revela alguns aspectos interessantes, e de certa forma complementares entre si, que ajudam a pensar esse momento pontual da vida literária do jovem Machado de Assis, que, como também se sabe, sempre foi carente de maiores informações. De um lado, e do ponto de vista estético-temático, "O grito do Ipiranga" apresenta na sua fatura um predominante tom nacionalista, bem ao gosto da tradição romântica brasileira, que, como se mostrará, aparece tanto na representação hiperbólica do fundador do Império, d. Pedro I - "O herói libertador, valente e ousado!" , quanto na representação da própria natureza local - "[...] Inda o vento das florestas/ Que as noites tropicais respiram frescas" - como marca de inerente nacionalidade literária; e, de outro, do ponto de vista histórico-biográfico, também joga algumas luzes sobre os primeiros movimentos da inserção intelectual do jovem poeta na grande imprensa do Rio de Janeiro, no caso, no Correio Mercantil.

Para início de conversa, observe-se que "O grito do Ipiranga" machadiano dialoga literariamente com uma passagem do segundo tomo de $A$ Independência do Brasil, poema épico algo problemático do prolífico escritor Antônio Gonçalves Teixeira e Sousa, saído em março de 1855, o primeiro tomo saiu em agosto de 1847, ambos publicados sob os cuidados do dileto amigo do autor, o famoso editor Francisco de Paula Brito.

\section{1. "O grito do Ipiranga", de Machado de Assis}

No dia 7 de setembro de 1856, alguns fragmentos do segundo tomo de A Independência do Brasil foram publicados nos três principais jornais da corte. Não se sabe se por iniciativa de Teixeira e Sousa, ou, o que seria mais provável como forma de propaganda do livro, por iniciativa do editor Paula Brito, já que apareceram em espaços pagos. No Diário do Rio de Janeiro, as dezoito primeiras estrofes do Canto XII, na seção "Comunicações" (SOUSA, 1856a, p. 2). No Jornal do Commercio, antecedido por irônico título - "Cada

\footnotetext{
${ }^{3}$ Nessa perspectiva, tanto Galante de Sousa, "a colaboração [no Correio Mercantil] de Machado de Assis começa em outubro do mesmo ano [1858] e estende-se até março de 1868, embora seja pouco frequente" (SOUSA, 1955, p. 208), quanto Jean-Michel Massa, "Publicou [Machado de Assis], em outubro do mesmo ano [1858], seu primeiro texto no Correio Mercantil" (MASSA, 1965, p. 185), apontavam a então primazia de "Esperança".
} 
um festeja a Independência a seu modo" - mais sete estrofes do Canto XII, estas, nas "Publicações a Pedido", remetiam ao final do poema (SOUSA, 1856b, p. 2). E, por fim, em lugar de destaque, ocupando a primeira e segunda páginas do Correio Mercantil, o fragmento mais longo, nada menos que 26 estrofes (CXXV a CL) do Canto XI, tematizando o momento mais simbólico da independência brasileira, o próprio grito do Ipiranga (SOUSA, 1856c, p. 1-2). O fragmento narra desde o momento da chegada de $\mathrm{d}$. Pedro ao riacho do Ipiranga, entremeado tanto por um sonho profético inicial quanto pelo embate entre a "horrível tentação" do Demônio do Despotismo e o derradeiro convencimento do príncipe português pelo Anjo do Brasil, referendado pelo Anjo da Memória a lhe garantir que teria seu nome aclamado “[...] entre os Heróis da Liberdade/ [...] com eterna auréola de Glória!”, até o momento propriamente do grito de libertação:

\section{CXXV}

Enfeitiçando um prado voluptuoso

Onde vegetam lépidos verdores,

Volve o Ipiranga o curso anfractuoso

Perfumado do bálsamo das flores.

Encantam este espaço deleitoso

Os hinos dos voláteis amadores:

Diríeis a campina afortunada

De Amor, das Graças mágica morada!

\section{CXXVI}

Sê, campo augusto, sem abençoado!

Caroável te seja a Natureza!

Sempre, ó preclaro Rio celebrado,

Te orne florente genial beleza,

Dos frescores das brisas bafejado!

Teatro da mais nobre gentileza,

Não precisa da Musa a etérea glória

Para ser imortal tua Memória!

\section{CXXVII}

Sem parar caminhando o moço ardente

Para neste lugar formos, e grato;

Com sua pouca, mas alegre gente

Nas margens pernoitou deste regato:

Até mui tarde conversou contente,

Mui tarde procurou do sono o trato: 
Machado de Assis em Linha - Universidade de São Paulo http://machadodeassis.fflch.usp.br - Artigo

Aquele corpo assim tão fatigado

Deitou-se e adormeceu mui sossegado!

\section{CXLVIII}

Embevecido então neste momento

Perante esta grandeza tão notória, Cheio d'entusiasmo, e de ardimento

Crê que lhe brada o Anjo da Memória:

- Se partes, ao teu nome esquecimento!

- Se ficas, ao teu nome a Honra, a Glória!

"À Hora, à Glória!" (Exclama em nobre ira)!

E o tope lusitano ao chão atira!

\section{CXLIX}

Dizendo, dos amigos ladeado,

A destra sobre a cruz da espada punha:

"Que vai ser grande Império inaugurado

Eu juro, e tomo o Céu por testemunha!"

N'um generoso ímpeto arroubado,

Da bainha arrancando a espada, a empunha...

"Eis o que decidir vai a vitória!

Brasil, aqui se libra a tua glória!

\section{CL}

Nada mais de união! d'hora em diante

Portugal para nós seja estrangeiro!

Viverá para si nobre e possante

O venturoso reino Brasileiro!

Juremos pois, amigos, neste instante,

Com ânimo fiel, nobre, e guerreiro,

Seguir da cara Pátria a livre sorte,

Bradando sempre - Independência, ou Morte! -"

(SOUSA, 1856c, p. 1-2)

No entanto, antes de tratar de "O grito do Ipiranga" machadiano, é importante relembrar que, no dia 2 de dezembro de 1855, o jovem poeta fizera uma primeira homenagem ao filho do fundador do império brasileiro, que então completava trinta anos, publicando o "Soneto a S.M. o imperador, o senhor d. Pedro II" na primeira página da Marmota Fluminense. 
Provavelmente a pedido de Paula Brito, que, ao lado do poema machadiano, publicou o artigo "Dois de dezembro" em louvor a d. Pedro II, ${ }^{4}$ pois, além de súdito fiel, o editor, em fins de 1850, já havia nomeado o seu mais ambicioso empreendimento comercial justamente de Empresa Tipográfica Dois de Dezembro, que, a despeito da coincidência de ser também o dia de seu aniversário e o de Teixeira e Sousa, fora obviamente escolhido em honra do imperador, que, inclusive, era o primeiro acionista da empresa. ${ }^{5}$

Na prática, o referido artigo de Paula Brito acabava por referendar o soneto do jovem Machado, que, antes de assinar com nome completo, apresentava-se respeitosamente como "reverente súdito". Em tom solene, que minava a espontaneidade do texto, algo denunciando a sua natureza de "encomenda", e ainda, em licença poética, tratando o imperador por "tu", o moço poeta, por sua vez, não mirava por acaso o "Monarca esclarecido", pois, no fundo, era a chance real de se fazer conhecido aos olhos reais do sócio de Paula Brito:

Nesse trono, Senhor, que foi ungido

Por um povo já livre, e sustentado

Por ti, que alimentando as leis, o estado

Hás na História teu Nome engrandecido;

Nesse trono, Senhor, onde esculpido

Tem a destra de Eterno um nome amado

Vês nascer este dia abrilhantado

Sorrindo a ti, Monarca esclarecido!

Eu te saúdo neste dia imenso!

De Clemência, de Justiça e sã Verdade

Queimando às piras perfumoso incenso!

Elevado aos umbrais da imensidade

Terás fama, respeito, e amor intenso

\footnotetext{
${ }^{4}$ Nos dois parágrafos iniciais, Paula Brito escreveu: "É este um Dia, cuja radiante aurora todos os Brasileiros deveriam saudar cheios de júbilo, e de um verdadeiro entusiasmo; porque depois do Dia 7 de Setembro de 1822, e do Dia 25 de Março de 1824, nenhum outro como ele deve ser desejado, porque, como ele, nenhum outro faz a glória do Brasil, o orgulho dos Brasileiros! // A vida do Senhor D. Pedro II é uma garantia de paz, união, e de estabilidade para o Império em geral; porque essa vida pertence mais ao país, do que Àquele que, cheio de privações a desfruta, como Entidade precisa para curar e todos os mais do que de Si próprio; vida que se prendem milhares de outras vidas, e cuja morte seria causa forçada de milhares outras mortes!" (BRITO, 1855, p. 1-2).

${ }^{5}$ Em dezembro de 1851, Paula Brito publicou um anúncio oferecendo ações da Empresa Tipográfica Dois de Dezembro, dizendo restar apenas 17 das 75 ações, juntamente com a relação dos acionistas que começava por "Suas Majestades Imperiais" (MARMOTA NA CORTE, 1851, p. 4).
} 
Um Nome transmitido à Eternidade!

(ASSIS, 1855b, p. 1)

Em outras palavras, queimar "às piras perfumoso incenso" ao imperador era gesto necessário, ou melhor, ritual de passagem a que se submetiam, por razões óbvias, todos os literatos locais e até alguns estrangeiros. E como não podia fugir à regra, o jovem Machado de Assis, depois de mirar o "filho", agora se voltaria para o "pai”, publicando no Correio Mercantil o seu "O grito do Ipiranga", que, como se disse, saiu na edição seguinte ao aparecimento dos fragmentos épicos de Teixeira e Sousa, e correspondendo aos dias 8 e 9 de setembro de 1856. Como o poema machadiano saiu numa seção - "Variedade" - que, apesar de não ter periodicidade fixa, ocupava sempre um lugar de destaque no jornal liberal, às vezes na primeira, outras, na segunda página, é de se supor que a publicação teria sido paga ou ao menos precisou contar com a boa vontade, ou melhor, com o favor de um dos redatores, o que, nos dois casos, talvez tenha ocorrido pela providencial ajuda de Paula Brito e seu reconhecido trânsito pela imprensa da corte. ${ }^{6}$

Por ser um texto de juventude, o que de antemão explica a qualidade estética hesitante e a evidente presença de traços românticos na fatura literária, "O grito do Ipiranga", a despeito de seguir a sugestão temática de Teixeira e Sousa, é estruturalmente organizado em nove estrofes irregulares com decassílabos brancos, o que, por conta do contorcionismo sintático dos versos, potencializou ainda mais o tom igualmente solene que o atravessa. Eis o texto:

Liberdade!... Farol divinizado! -

Sob o teu brilho a humanidade e os séculos

Caminham ao porvir. Roma as algemas

Quebrou dos filhos que a opressão lançara

Dentre a sombra de púrpura dos Césares,

Que envolvia Tarquínio em fogo e sangue,

Cheia de tua luz e estimulada

Por teu nome divino - essa palavra

Imensa como as vozes do Oceano.

Sublime como a ideia do infinito!

\footnotetext{
${ }^{6}$ De certa forma, atestando tal trânsito pela imprensa, Paula Brito, poucos dias depois de o poema machadiano aparecer, publicou "a pedido" do Correio Mercantil uma elegia, antecedida de carta, à memória do importante político conservador e fiador da política de conciliação dos partidos, o marquês de Paraná (Cf. BRITO, 1856, p. 1).
} 
Tal como Roma a terra americana, Um dia alevantando ao sol dos trópicos A fronte que domina os estandartes, Saudou teu nome majestoso e belo E o brado imenso - Independência ou morte! Soltado lá das margens do Ipiranga. Foi nos campos soar da eternidade.

Desenrola nas turbas populares Dos livres a bandeira o herói tão nobre, Digno dos louros festivais que outrora Roma dava aos heróis entre os aplausos Do povo que os levava ao Capitólio! Ele foi como o César de Marengo; Sua voz como a lava do Vesúvio Levada pela voz da imensidade Foi do Tejo soar nas margens, onde Estremeceu de susto o lusitano!

Ipiranga!... Ipiranga!... A voz das brisas Este nome repete nas florestas! Caminhante! Eis ali onde primeiro Soou o brado - Independência ou morte! O homem secular levando as águias Por entre os turbilhões de pó, de fumo, Ostentando nos livres estandartes O lúcido farol de um século ovante, Mais sublime não foi nem mais valente Que Pedro o herói, da América travando Do farol da sagrada liberdade, E acordando o Brasil, escravizado, Sob férreos grilhões adormecido.

Somos livres! - Nas páginas da história Nosso nome fulgura - ali traçado Foi por Deus, que do herói guiando o braço, Nas folhas o escreveu do eterno livro.

Somos livres! - No peito brasileiro A ideia da opressão não se acalenta! Somos já livres como a voz do oceano, Somos grandes também como o infinito, Como o nome de Pedro e dos Andradas! 
Seja bendito o dia em que Colombo César dos mares, afrontando as ondas, À Europa revelou um Novo Mundo; Ele nos trouxe o cetro das conquistas Nas mãos de Pedro - o fundador do Império!

O herói calcando os pedestais da história, Ergue soberbo aos séculos vindouros A fronte majestosa! Imenso vulto! É ele o sol da terra brasileira! Neste dia de esplêndidas lembranças No peito brasileiro se reflete O nome dele - como um sol ardente Brilha dourado no cristal dos prismas!

Tomando o sabre, dominou dois mundos O herói libertador, valente e ousado! Ele, o tronco da nossa liberdade, Foi como o cedro secular do Líbano, Que resiste ao tufão e às tempestades!

Ipiranga! Inda o vento das florestas Que as noites tropicais respiram frescas Parecem murmurar nos seus soluços O brado imenso - Independência ou morte! Qual o trovão nos ecos do infinito!

Disse ao guerreiro o Deus da Liberdade: Liberta o teu Brasil num brado augusto, E o herói valente libertou num grito! (ASSIS, 1856, p. 2)

Entre as muitas possibilidades de leitura, o que sempre implica escolhas e recusas, "O grito do Ipiranga" será lido a partir de dois momentos distintos e bem demarcados: no primeiro, restrito apenas e tão somente à primeira estrofe, mas cuja importância perpassa todo o corpo do poema. O eulírico machadiano, ao invocar a "Liberdade!" como um "Farol divinizado!" da humanidade, recorreu ao testemunho histórico de Tito Lívio e sua História de Roma, para traçar o simbólico paralelo entre a formação da república romana a Independência do Brasil. E, assim, ancorando-se na ideia que "Tal como 
Roma a terra americana,/ Um dia alevantando [...]”, e sem, no entanto, qualquer menção ao ultraje de Lucrécia que fora o estopim do processo de deposição do rei etrusco, Lúcio Tarquínio Soberbo (Cf. LÍVIO, 2008, p. 173185), sobrevalorizou o caráter mítico assumido pelo "[...] brado imenso Independência ou morte!”, que, “ao sol dos trópicos”, “[...] lá das margens do Ipiranga./ Foi nos campos soar da eternidade".

Já no segundo momento, composto pelas oito estrofes restantes, o eulírico insistiu, por um lado, e na maior parte dos versos, num idêntico e crescente processo de caracterização mítica de d. Pedro, seja comparando-o a Napoleão Bonaparte - "Ele foi como o César de Marengo;" - ou ao "tronco da nossa liberdade”, metaforizado pelo "cedro secular do Líbano,/ Que resiste ao tufão e às tempestades!", seja amplificando ao extremo "Sua voz como a lava do Vesúvio/ Levada pela voz da imensidade”, cuja força do grito libertador ressoaria por todos os cantos do país - "Qual o trovão nos ecos do infinito!”. E, ao intensificar a louvação ao fundador do Império, também reforçou, a exemplo do Anjo da Memória de Teixeira e Sousa, que "O herói calcando os pedestais da história,/ Ergue soberbo aos séculos vindouros/ A fronte majestosa! Imenso vulto!”, e, ao mesmo tempo, reconheceu-o não somente como o imprescindível "sol da terra brasileira", mas, sobretudo e obviamente, como aquele que, depois de ouvir "o Deus da Liberdade", libertou o "Brasil num brado augusto".

Por outro lado, e de não menor importância, sobrevalorizou, embora em poucos versos, o igualmente simbólico lugar da independência, o riacho Ipiranga, a quem, a própria natureza brasileira fazia solenes reverências, seja em “Ipiranga!... Ipiranga!... A voz das brisas/ Este nome repete nas florestas!”, seja em "Ipiranga! Inda o vento das florestas/Que as noites tropicais respiram frescas/ Parecem murmurar nos seus soluços/ O brado imenso [...]”. Aliás, neste último caso, e ao lado de outras imagens poéticas como "Somos já livres como a voz do oceano," ou "O nome dele - como um sol ardente", o jovem Machado de Assis apenas respondia à necessidade romântica, repisada à exaustão, de exprimir, como metáfora de brasilidade, aspectos da natureza tropical, reafirmando a importância literária da “cor local”.

Enfim, se, ao menos neste poema de juventude, Machado de Assis usou e abusou da dicção "pátria amada", aceitando os ditames românticos, não demoraria muito tempo, na verdade, pouco menos de dois anos, para abandonar essa obrigatoriedade, notadamente no que diz respeito às expectativas em torno do próprio desenvolvimento da literatura brasileira, que, para ele, não deveria ser feito às pressas, nem somente "sob a ação 
influente de uma literatura ultramarina”, como escreveria, em abril de 1858, em "O passado, o presente e o futuro da literatura", publicado em duas partes em A Marmota. Pois, para o jovem crítico literário:

[...] após o Fiat político, devia vir o Fiat literário, a emancipação do mundo intelectual, vacilante sob a ação influente de uma literatura ultramarina. Mas como? É mais fácil regenerar uma nação, que uma literatura. Para esta não há gritos de Ipiranga; as modificações operamse vagarosamente; e não se chega em um só momento a um resultado. (ASSIS, 1858a, p. 1)

\section{A persistência do tópos histórico: dois exemplos}

A partir da publicação do poema "A saudade" na Marmota Fluminense, em 5 de outubro de 1855, o jovem Machado de Assis, pela primeira vez, tanto usou o decassílabo branco quanto estabeleceu um diálogo literário com o universo mítico greco-latino (ASSIS, 1855a, p. 3). Em "O grito do Ipiranga", no entanto, além de insistir no mesmo tipo de verso, o poeta, também pela primeira vez, estabeleceu outro diálogo com a cultura antiga, agora de matiz histórico, com os episódios que explicavam a deposição de Lúcio Tarquínio Soberbo e a consequente fundação da república romana, pinçados junto à História de Roma de Tito Lívio.

Assim, e levando em conta a "essência" da conhecida sugestão crítica de Silviano Santiago, para quem:

Já é tempo de se começar a compreender a obra machadiana como um todo coerentemente organizado, percebendo que certas estruturas primárias e primeiras se desarticulam e rearticulam sob formas de estruturas diferentes, mais complexas e mais sofisticadas, à medida que seus textos se sucedem cronologicamente. (SANTIAGO, 1978, p. 29-30)

E, guardando as devidas proporções, já que, ao invés de se focar no processo complexo das estruturas literárias como um todo ou mesmo no jogo contínuo (e talvez obsessivo) de desarticulação e rearticulação estruturais, pretende-se, na verdade, a partir do acolhimento da afirmação de Silviano Santiago, discutir como Machado de Assis dialogou em outros textos com os mesmos referenciais históricos. O que, nesse sentido, será restrito apenas e tão somente a duas crônicas posteriores, em que reaparecem, com soluções diferentes, o episódio de Tito Lívio usado em "O grito do Ipiranga”. 
A primeira crônica foi escrita e publicada vinte anos depois do poema, em 15 de setembro de 1876, na coluna "História de Quinze Dias", da revista Ilustração Brasileira, sob a assinatura de Manassés. Nesta crônica, Machado de Assis, entre os assuntos importantes da quinzena, repercutiu a "polêmica" na imprensa sobre o suposto exato lugar em que se dera o grito do Ipiranga. Mas, como o cronista citou no seu texto um dos participantes da contenda, é importante, ainda que brevemente, relembrar a polêmica.

Tudo começou com a carta do dr. Joaquim Antônio Pinto Júnior, ${ }^{7}$ enviada à Gazeta de Notícias, no dia 10 de setembro, relativa à questão suscitada sobre o ato da Proclamação da Independência, questionando algumas afirmações de outro artigo que versava sobre o papel histórico atribuído a José Bonifácio no contexto da independência brasileira, de autoria do dr. Miguel Antônio da Silva, ${ }^{8}$ publicado em $O$ Globo, no dia 7 de setembro (Cf. SILVA, 1876, p. 1).

$\mathrm{Na}$ carta resposta, o ilustrado dr. Joaquim Antônio não apenas afirmou que José Bonifácio fora um dos responsáveis por esse "grande pensamento" como também asseverou que o ato derradeiro, protagonizado por d. Pedro, não ocorrera às margens do Ipiranga, ao contrário do que a maior parte dos brasileiros até então supunha. E aproveitou a ocasião para discorrer sobre qual teria sido o exato lugar onde se dera, nas suas palavras, o "memorando acontecimento". Nesse sentido, sem disfarçar o tom professoral, explicou:

[...] Longe de mim querer roubar ao conselheiro José Bonifácio a parte direta que teve na nossa Independência, muito mais quando esta intervenção me foi muitas vezes relatada por seus respeitáveis irmãos e meus particulares amigos o velho Antônio Carlos e o venerando Martim Francisco!

A história porém não tem paixões; encarando mais os princípios do que os homens, faz destes menção somente quando representam ideias,

\footnotetext{
7 Joaquim Antônio Pinto Júnior (1817-1880), bacharel de Direito pela Faculdade de São Paulo (1839), "[...] dedicou-se à advocacia, colhendo louros na tribuna judiciária [...]. Foi professor de francês e de inglês do curso anexo à faculdade [...], foi deputado à assembleia da citada província em várias legislaturas; exerceu outros cargos de eleição popular e de nomeação do governo, como o de diretor e advogado das aldeias indígenas de Carapicuíba e Barueri, e organizou por ocasião da guerra contra o Paraguai um batalhão de voluntários [...]. Era cavaleiro da ordem da Rosa e da de Cristo, sócio do Instituto Histórico e Geográfico Brasileiro, do Instituto da Ordem dos Advogados Brasileiros, [e] da Sociedade Auxiliadora da Indústria Nacional [...]” (BLAKE, 1898, p. 89-91).

${ }^{8}$ Miguel Antônio da Silva (1832-1879) “[...] era doutor em matemáticas pela antiga Academia Militar [...]; do Conselho de sua majestade o imperador; comendador da ordem da Rosa; cavaleiro da ordem de S. Bento de Avis, da de Cristo e da ordem austríaca de Francisco José; sócio do Instituto Histórico e Geográfico Brasileiro; do Imperial Instituo de Agricultura; do Instituto Brasileiro de Ciências Naturais; do Instituto Politécnico Brasileiro, etc.” (BLAKE, 1900, p. 265).
} 
quando simbolizam princípios, acontecimentos de vulto e importância social.

José Bonifácio é um nome essencialmente ligado à história do Brasil, [...], mas em relação à nossa Independência, é mister não concentrar somente nele um triunfo para o qual trabalharam ativamente tantas inteligências robustas, que a história fria, calma e imparcial um dia há de registrar!

Em relação ao local em que foi proclamada a Independência, direi ao meu amigo, que o humilde e cristalino ribeiro denominado Ipiranga emprestou o seu nome à nossa história pátria, porque assim o quiseram os primeiros escritores que trataram do fato.

A Independência foi proclamada, ou antes - o brado Independência ou morte - foi dado no alto da montanha ou colina, a mais talvez de mil braças do ribeiro Ipiranga, no lugar pertencente aos denominados campos de Piratininga.

Em 1846, quando o sr. d. Pedro II visitou pela primeira vez a província de S. Paulo, no alto dessa colina (chamada do Ipiranga depois da Independência) ergueu-se um majestoso, mas provisório pavilhão, que o tempo destruiu, mas ainda ali existem vestígios, e esse (segundo o testemunho tomado dos srs. velhos paulistas que assistiram ao ato) foi designado o lugar em que o príncipe se apeou para ler a correspondência do Reino e onde proferiu aquelas memorandas palavras.

Nem eu, nem o meu estimável amigo escrevemos agora a história desse memorando acontecimento, mas bom é que fique liquidado desde já, enquanto é tempo, este ponto importante, para que mais tarde a tradição não seja distraída da esteira da verdade. (PINTO JÚNIOR, 1876, p. 1)

Por sua vez, Machado de Assis, na primeira parte da crônica, teceu considerações genéricas sobre as comemorações do 7 de setembro - "Este ano parece que remoçou o aniversário da Independência. [...] Houve, realmente, mais entusiasmo este ano" - e, depois de comentar brevemente as festividades na corte - "As iluminações foram brilhantes" - rematou-a, com pitada de ironia e como forma de "gancho" para o que escreveria depois, afirmando que "Não morreu, nem pode morrer, a lembrança do grito do Ipiranga" (ASSIS, 1876, p. 94). Pois, ao longo de toda a segunda parte e com o providencial aumento na dose de ironia, dedicou-se a argumentar contrariamente à referida tese do "ilustrado paulista":

Grito do Ipiranga? Isso era bom antes de um nobre amigo, que veio reclamar pela Gazeta de Notícias contra essa lenda de meio século. 
Segundo o ilustrado paulista não houve nem grito nem Ipiranga. Houve algumas palavras, entre elas a Independência ou morte, - as quais todas foram proferidas em lugar diferente das margens do Ipiranga. Pondera o meu amigo que não convém, a tão curta distância, desnaturar as verdades dos fatos.

Ninguém ignora a que estado reduziram a história romana alguns autores alemães, cuja pena, semelhante a uma picareta, desbastaram os inventos de dezoito séculos, não nos deixando mais que uma certa porção de sucessos exatos. Vá feito! O tempo decorrido era longo e a tradição estava arraigada como uma ideia fixa. Demais, que Numa Pompílio houvesse ou não existido é coisa que não altera sensivelmente a moderna civilização. Certamente é belo que Lucrécia haja dado um exemplo de castidade às senhoras de todos os tempos; mas se os escavadores modernos me provarem que Lucrécia é uma ficção e Tarquínio uma hipótese, nem por isso deixa de haver castidade... e pretendentes.

Mas isso é história antiga. O caso do Ipiranga data de ontem. Durante cinquenta e quatro anos temos vindo a repetir uma coisa que o dito meu amigo declara não ter existido. Houve resolução do príncipe d. Pedro, independência e o mais; mas não foi positivamente um grito, nem ele se deu nas margens do célebre ribeiro. Lá se vão as páginas dos historiadores; e isso é o menos. Emendam-se as futuras edições. Mas os versos? Os versos emendam-se com muito menos facilidade.

Minha opinião é que a lenda é melhor do que a história autêntica. A lenda resumia todo o fato da independência nacional, ao passo que a versão exata o reduz a uma coisa vaga e anônima. Tenha paciência o meu ilustrado amigo. Eu prefiro o grito do Ipiranga; é mais sumário, mais bonito e mais genérico. (ASSIS, 1876, p. 94)

A despeito de "se preocupar" mais com o que a mudança de versão de fatos históricos causaria nos versos, que se emendariam "com muito menos facilidade", do que com os livros de história, Machado, para sustentar a opinião "que a lenda é melhor do que a história autêntica", recorreu justamente à história antiga de Tito Lívio. Ao mesmo tempo, o cronista não deixou de alertar que, no caso de Lucrécia e seu "exemplo de castidade às senhoras de todos os tempos”, a eventual ficção dessa história não implicaria necessariamente a inexistência histórica - afinal, "nem por isso deixa de haver castidade... e pretendentes", ${ }^{9}$ pois, lenda ou não, a pena do famoso historiador já a incrustara na história ocidental.

\footnotetext{
${ }^{9}$ En passant, por falar em castidade e pretendentes, relembre-se de que o narrador enganoso de Dom Casmurro, no capítulo XXXVII ("A alma é cheia de mistérios"), também se referiu, com veladas "segundas intenções", à Lucrécia: "As palavras [de Capitu] pareciam ser uma moça consigo mesma, uma
} 
A segunda crônica machadiana apareceu bem mais tarde na coluna "A Semana"10 da Gazeta de Notícias, em 5 de agosto de 1894, e, por assim dizer, adquiriu vida própria, tornando-se conhecida como "O punhal de Martinha", título dado por Mário de Alencar, que organizou a primeira antologia das crônicas machadianas de "A Semana" (ASSIS, s.d., p. 143-147). Nesta crônica de maturidade, a exemplo do que fizera no poema de juventude, Machado de Assis traçou outro paralelo entre a história romana e a realidade brasileira, agora, no entanto, mais ousado e complexo, focado nos diferentes destinos de dois punhais. O primeiro, tornado "clássico" por Tito Lívio em sua História de Roma e, por isso mesmo, há muito reconhecido, cantado em prosa e verso; e o segundo, mais modesto, fadado a ser consumido pela "ferrugem da obscuridade". Ou seja, de um lado, o punhal que Lucrécia usou para se suicidar, depois de ultrajada por Sexto Tarquínio; de outro lado, o punhal de Martinha, "rapariga franzina" e moradora de Cachoeira no interior baiano, que, ante a ameaça de igual sorte de ultraje, foi usado, ao contrário do gesto dramático da matrona romana, para "furar" um certo João Limeira que a importunava.

De início, para armar o entrecho da disparatada comparação, o cronista, parafraseando Tito Lívio, apresentou o drama de Lucrécia e o destino do punhal "que serviu de lábaro à revolução" (ASSIS, 1894, p. 1). E, num segundo momento, frente a "essa parcialidade dos tempos, que [...] transmitem as ações encomendadas nos bons livros", começou propriamente a desenhar o paralelo de armas, levantando como "as circunstâncias dos dois atos são diversas": o fato de o punhal de Martinha não ser inferior ao de Lucrécia, "mas até certo ponto é superior" (ASSIS, 1894, p. 1).

Por fim, além de aludir a outras famosas armas que "farão cortejo ao punhal de Lucrécia", Machado de Assis sentenciou que, pela "desigualdade dos destinos", o punhal de Martinha iria mesmo "rio abaixo do esquecimento". Mas, ao contrário da crônica anterior, salvo o desconto da irônica afirmação, em que desafiava os escavadores modernos a lhe provarem que Lucrécia era

vez que, desde manhã, era mulher, como eu era homem. Achei-lhe graça, e, para dizer tudo, quis provarlhe que era moça inteira. Peguei-lhe levemente na mão direita, depois na esquerda, e fiquei assim pasmado e trêmulo. Era a ideia com mãos. Quis puxar as de Capitu, para obrigá-la a vir atrás delas, mais ainda agora a ação não respondeu à intenção. Contudo, achei-me forte e atrevido. Não imitava ninguém; não vivia como os rapazes, que me ensinassem anedotas de amor. Não conhecia a violação de Lucrécia [...]” (ASSIS, 1994, p. 848-849) (Grifos nossos).

${ }^{10}$ Sobre a importância de "A Semana", coluna da Gazeta de Notícias, publicada entre 1892 e 1897, John Gledson afirma que "[...] é, sem dúvida, a série [de crônicas] mais famosa do autor, e aquela que Machado mais se identificou pessoalmente [...]". "Tudo indica que empreendeu essa nova série como um projeto de fôlego; e de fato é a sua série mais longa, com um total de 248 crônicas. Eram publicadas todos os domingos, com o título em maiúsculas, no jornal que era talvez o mais popular e respeitado do Rio, conhecido pela oposição sensata e moderada ao regime republicano" (GLEDSON, 2006, p. 207 e 210). 
uma ficção, talvez agora convencido por aqueles mesmos "autores alemães", e dizendo-se, ele próprio, amante de "ficções”, concluiu, novamente com ironia, que "o punhal de Martinha, que existiu e existe, não logrará ocupar um lugarzinho ao pé do de Lucrécia, pura ficção” (ASSIS, 1894, p. 1).

Mais que evidente, essa crônica de maturidade é bem mais sofisticada. No paralelo entre os punhais e, por tabela, no paralelo de Lucrécia e Martinha, a solução machadiana, em comparação irônica, traz à tona, em diálogo com a perspectiva universal, as inerentes incongruências da sociedade local. Nessa perspectiva, para Roberto Schwarz, ${ }^{11}$ que, na leitura da mesma crônica, compreende universalismo e localismo como ideologias,

Ao desenvolver uma escrita em que dois registros contracenam a seco e com ironia, incongruentes, complementares e descambando no seu contrário, Machado criava um equivalente estilístico dessa constelação história, além de colocá-lo em movimento, com seus fortes momentos de verdade. O universal é falso, e o local participaria do universal se não estivesse isolado e posto à parte, em degrau abaixo.

[...] A nota dissonante, sem solução em perspectiva, tinha possibilidades cômicas e representatividade nacional, além de funcionar como caricatura do presente do mundo, em que as experiências locais deixam mal a cultura autorizada, num amesquinhamento recíproco, que é um verdadeiro "universal moderno". (SCHWARZ, 2012, p. 41 e 43)

Em suma, temperadas de finas e crescentes ironias, as duas crônicas seja a discussão bem-humorada sobre o grito do Ipiranga na Ilustração Brasileira, seja a disparatada, mas engenhosa comparação de "O punhal de Martinha” na Gazeta de Notícias - confirmam, em outros termos e com soluções próprias, a sugestão de Silviano Santigo, sobretudo quando se percebe os modos distintos que Machado de Assis usou tanto para se apropriar quanto para se reapropriar dos mesmos referenciais históricos de Tito Lívio. Noutras palavras, a complexificação literária machadiana, além de formal, também está, e não é novidade nenhuma, no reaproveitamento temático, o que, em igual sentido, implica estratégias semelhantes nas faturas de contos e romances. No entanto, a grande ironia de toda essa história, o que não deixa de ser obviamente ainda mais irônico, é chegar até aqui para descobrir que, no caso das duas crônicas, a ponta do fio da meada temática, a História de Roma

\footnotetext{
${ }^{11}$ Roberto Schwarz, ao discutir a recepção internacional da obra de Machado de Assis, tendo como principal interlocutor o crítico americano Michael Wood, finaliza o ensaio "Leituras em competição" com a análise de "O punhal de Martinha" (SCHWARZ, 2012, p. 9-43). Para o debate entre os críticos, confira GUIMARÃES, 2017, p. 252-259.
} 
de Tito Lívio, já estava presente em "O grito do Ipiranga”, escondida num simples e desconhecido poema de juventude.

Referências

ASSIS, Machado de. “A saudade”. Marmota Fluminense. n. 632, p. 3, 5 out. 1855a. . "Soneto a S.M. o imperador, o senhor d. Pedro II". Marmota Fluminense. n. 654, p. 1, 2 dez. 1855b.

. "O grito do Ipiranga". Correio Mercantil. n. 248, p. 2, 8 e 9 set. 1856.

. "O passado, o presente e o futuro da literatura". A Marmota. (Parte I) n. 941, p. 1-2, 9 abr. 1858a; (Parte II) n. 945, p. 1-2, 23 abr. 1858b.

. "Esperança". Correio Mercantil. n. 290, p. 2, 25 out. 1858c.

. "História de Quinze Dias”. Ilustração Brasileira. n. 6, p. 94, 15 set. 1876.

"A Semana". Gazeta de Notícias. n. 216, p. 1, 5 ago. 1894.

. "O punhal de Martinha”. "A Semana” por Machado de Assis. Edição coligida por Mário de Alencar. Rio de Janeiro; Paris: Livraria Garnier, s.d. [1910 ou 1914?].

. Dom Casmurro. Obra completa. v. 1. Rio de Janeiro: Nova Aguilar, 1994.

CORREIO MERCANTIL. n. 248, p. 1, 8 e 9 set. 1856.

BLAKE, Augusto Victorino Alves Sacramento. Dicionário bibliográfico brasileiro. v. 4. Rio de Janeiro: Imprensa Nacional, 1898.

. Dicionário bibliográfico brasileiro. v. 6. Rio de Janeiro: Imprensa Nacional, 1900.

BRITO, Francisco de Paula. "Dois de dezembro". Marmota Fluminense. n. 654, p. 12, 2 dez. 1855.

. "À irreparável perda do marquês de Paraná”. Correio Mercantil. n. 253, p. 1, 11 set. 1856.

COZER, Raquel. "Poema desconhecido que Machado de Assis escreveu aos 17 anos é descoberto". Folha de S. Paulo, n. 31.391, p. E-1, 14 mar. 2015.

GLEDSON, John. Por um novo Machado de Assis. São Paulo: Companhia das Letras, 2006.

GUIMARÃES, Hélio de Seixas. Machado de Assis, o escritor que nos lê. São Paulo: Editora UNESP, 2017.

LÍVIO, Tito. História de Roma: Livro I - a Monarquia. Trad. Mônica Vitorino; introdução e notas Júlio Cesar Vitorino. Belo Horizonte: Crisálidas, 2008.

MARMOTA NA CORTE. n. 215, p. 4, 2 dez. 1851.

MASSA, Jean Michel (Org.). Dispersos de Machado de Assis. Rio de Janeiro: INL, 1965.

. "A biblioteca de Machado de Assis". In: A biblioteca de Machado de Assis. Organização José Luís Jobim. $2^{\mathrm{a}}$ ed. Rio de Janeiro: Academia Brasileira de Letras; Topbooks, 2008.

PINTO JÚNIOR, Joaquim Antônio. "Carta". Gazeta de Notícias. n. 250, p. 1, 10 set. 1876. 
SANTIAGO, Silviano. "Retórica da verossimilhança". In: Uma literatura nos trópicos: ensaios sobre dependência cultural. São Paulo: Perspectiva, 1978.

SCHWARZ, Roberto. Martinha versus Lucrécia. São Paulo: Companhia das Letras, 2012.

SILVA, Miguel Antônio da. “José Bonifácio de Andrade e Silva”. O Globo. n. 241, p. 1, 7 set. 1876.

SOUSA, Antônio Gonçalves Teixeira e. "A Independência do Brasil”, Diário do Rio de Janeiro. n. 249, p. 2, 7 set. 1856a.

“A Independência do Brasil”, Jornal do Commercio. n. 249, p. 2, 7 set. 1856 b.

“A Independência do Brasil”, Correio Mercantil. n. 247, p. 1-2, 7 set. 1856c.

SOUSA, José Galante de. Bibliografia de Machado de Assis. Rio de Janeiro: INL, 1955. VITORINO, Júlio Cesar. "Introdução”. In: LÍVIO, Tito. História de Roma: Livro I - a Monarquia. Trad. Mônica Vitorino; introdução e notas Júlio Cesar Vitorino. Belo Horizonte: Crisálidas, 2008.

WILTON JOSÉ MARQUES é doutor em literatura brasileira pela Universidade de São Paulo. Professor de literatura brasileira e teoria literária do Departamento de Letras, do Programa de Pós-Graduação em Estudos de Literatura da Universidade Federal de São Carlos (UFSCar) e do Programa de Pós-Graduação em Estudos Literários da Universidade Estadual Paulista Júlio de Mesquita Filho (Unesp - Araraquara). Em 2011, recebeu o Prêmio Jabuti na categoria Crítica e Teoria Literária pelo livro Gonçalves Dias: o poeta na contramão (EDUFSCar, 2010). Entre suas principais publicações estão $O$ poeta do lá (EDUFSCar, 2014), O poeta sem livro e a pietà indígena (Editora da Unicamp, 2015) e Ao correr da pena (folhetins inéditos), de José de Alencar (EDUFSCar: 2017). 0 presente artigo faz parte da pesquisa "Machado de Assis e as primeiras incertezas", financiada pelo CNPq. Ehttps://orcid.org/0000-0003-2559-9331.

E-mail: will@ufscar.br.

Recebido: 12.05 .2020

Aprovado: 20.07.2020

Machado de Assis em Linha, São Paulo, v. 14, p.1-18, e237963, 2021

Este texto está licenciado sob uma Licença Creative Commons do tipo atribuição BY. 